\title{
6
}

\section{A Brief Case for Open Borders in Australia}

\section{Benjamin Powell}

Australia is a nation of immigrants. Just over 25 per cent of the Australian population is foreign born, ${ }^{2}$ and an additional quarter of the population has at least one foreign-born parent. Despite receiving large numbers of migrants, Australia remains sparsely populated. A land rich in natural beauty and resources remains lacking in its quantity of what economist Julian Simon referred to as the ultimate resource: people. ${ }^{3}$ Yet, as other papers have discussed, the Australian Government still imposes significant barriers to allowing more immigrants. These barriers limit low-skilled immigration as well as the migration of college-educated and other more skilled workers.

1 This chapter draws heavily on some of my prior published writing and modifies it to reflect my basic message delivered at the Unintended Consequences: The Impact of Migration Law and Policy Conference, 25-26 October 2013, The Australian National University, Canberra. In particular, I draw most heavily on some parts of Benjamin Powell and Zachary Gochenour, 'Broken Borders: Government, Foreign-born Workers, and the US Economy' (Policy Report, The Independent Institute, September 2013).

2 OECD, 'Key Indicators on International Migration'. Available at: www.oecd.org/els/mig/ke yindicatorsoninternationalmigration.htm.

3 Julian Simon, The Ultimate Resource (Princeton University Press, 1981). 
This chapter examines the economic consequences, both intended and unintended, of immigration. Although economic theory will be applied to Australia's circumstances, the general economic case for immigration is also applicable in other developed and relatively economically free countries.

Many objections to greater immigrant flows are grounded in economic fallacies. This chapter proceeds by documenting the basic economics of international trade in labour and examining the merits of three popular economic fallacies: that immigrants harm the economy; steal our jobs; and depress the wages of the native born. Finally, other fiscal, criminal, and political problems are briefly considered.

\section{Immigration's impact on the economy}

Contrary to many popular fears, ${ }^{4}$ immigrants improve the economic welfare of the native-born population. Free trade in labour, like trade in goods and services, frees Australians and permanent residents to do what is in their comparative advantage. In fact, the basic economic case for free trade in labour is not fundamentally different than that for trade in goods and services.

Trade barriers for goods and services have fallen considerably since the establishment of the General Agreement on Tariffs and Trade (GATT) in 1947. Support for free trade in goods and services commands more consent among economists than virtually any other issue. In fact, free trade has been a core issue for economists ever since Adam Smith's An Inquiry into the Nature and Causes of the Wealth of Nations (1776).

The basic case for free trade builds on the fact that different people in different places have different abilities to produce goods and services. If governments allow them to trade freely, market forces will naturally push each person (and country) to produce those goods and services that they can produce at the lowest cost and import those goods and

4 CNN correspondent Lou Dobbs is a prime example of the types of fears held by many in the general public. See 'Lou Dobbs calls economists "jackasses"', www.youtube.com/ watch? $\mathrm{v}=\mathrm{zoDb} 3 \mathrm{D} 7 \mathrm{~B} 2 \mathrm{Z}$. 
services that they could only produce at greater expense. As a result, market exchange creates more wealth than would be created in the absence of such exchange. ${ }^{5}$

Substitute labour mobility for the mobility of goods and services, and the process works in the same way. Given their abilities, interests, and costs, each labourer moves to where he can create relatively more value for others. If capital, natural resources, and goods and services were all perfectly mobile, labour mobility wouldn't be as economically important as it is.

But barriers to trade in goods and capital flows remain; some services must be provided in person, and, by definition, many natural resources are in a fixed geographical location. Thus, labour mobility remains crucial for our prosperity. In fact, the benefits of increasing labour mobility greatly dwarfs the gains that could be achieved through further removal of barriers to capital flows and trade in goods and services.

Economist Michael Clemens has documented that completely eliminating global barriers to immigration would result in net gains of $\$ 30$ to $\$ 90$ trillion for the world's economy (50 to 150 per cent of world GDP). ${ }^{6}$ Even a smaller migration of 5 per cent of people from poorer parts to wealthier parts of the world would result in wealth gains that exceed those that could be had by eliminating remaining trade and capital flow barriers.

Of course, many of the benefits Clemens estimates would go to the immigrants themselves. What about the net benefit of immigration to the native-born population? Harvard economist George Borjas is probably the most widely known academic critic of unfettered immigration, but even he admits that immigrants create net benefits for the native-born and, in the Concise Encyclopedia of Economics,

5 David Ricardo, On the Principles of Political Economy and Taxation (Cambridge University Press, 1817).

6 Michael Clemens, 'Economics and Emigration: Trillion-Dollar Bills on the Sidewalk? (2011)

25 Journal of Economic Perspectives 83. 
he puts this gain at $\$ 22$ billion a year in the United States. ${ }^{7}$ Applying this same methodology to Australia results in an estimated net benefit for the native-born population of $\$ 9$ billion. ${ }^{8}$

Relative to the $\$ 1.5$ trillion Australian economy, $\$ 9$ billion is a modest 0.6 per cent of GDP. Other methods of calculating the net benefits of immigration lead to larger numbers, though all remain modest as a percentage of the economy. ${ }^{9}$ However, it is important to keep in mind that the current level of benefits natives derive from immigration is related directly to the Australian Government's restrictive immigration policies. Obviously, more immigrants would increase the gains. Current policy also dictates that some migrants, including refugees, are ineligible to participate in the labour force. Even so, the important point is that economists have a wide agreement that immigration, like free trade, brings net benefits to the existing native-born population. ${ }^{10}$ Thus a smaller economy and lower standard of living are one of the unintended and undesirable consequences of restrictive immigration policies.

\section{Immigrants do not take jobs from the native born}

That immigrants take our jobs is probably the most repeated and most economically ignorant objection to immigration. It is a classic example of Bastiat's 'broken window fallacy' ('what is seen and what is not seen'). ${ }^{11}$ Everyone can see when an immigrant takes a job that was

7 George Borjas, 'Immigration' in David R Henderson (ed.), The Concise Encyclopedia of Economics (Liberty Fund, 2009) 253.

8 Calculated as GDP multiplied by $1 / 2 \mathrm{sem} 2$ where $\mathrm{s}=$ labour's share of GDP, $\mathrm{e}=$ the elasticity of labour demand with respect to the wage, and $\mathrm{m}=$ the fraction of the labour force that is foreign born.

9 See George Borjas, above fn 7, for some references to alternative methodologies.

10 See the Independent Institute's Open Letter on Immigration, its signatories, and the references at the end of the letter for evidence of this consensus. Alexander Tabarrok and David Theroux, 'Open Letter on Immigration', Independent Institute, 19 June 2006. Available at: www. independent.org/newsroom/article.asp?id=1727.

11 Frédéric Bastiat, 'What Is Seen and What Is Not Seen' in George B. de Huszar (ed.) Seymour Cain (trans.), Selected Essays on Political Economy (Foundation for Economic Education, 1848). In Bastiat's example, a window is broken and people erroneously believe that the town will become wealthier because now someone must be paid to replace it. They overlook the unseen fact that the money would have been spent elsewhere in the economy if the window had not been broken. 
held by a native-born worker. But not everyone sees the secondary consequence of the new jobs that are created because native-born labour has been freed up for more productive uses. In the market's process of creative destruction, jobs are created and destroyed all the time.

If, on balance, immigrants really did take jobs from existing nativeborn workers without new jobs being created, the same should be true any time we add more workers to the economy. As Figure 6.1 shows, the Australian civilian labour force has nearly doubled since 1978. ${ }^{12}$ Yet there has been no long-term increase in the unemployment rate. In 1978, the unemployment rate was 6.3 per cent, ${ }^{13}$ and currently it is 5.7 per cent. ${ }^{14}$ As more people enter the labour force, more people get jobs.

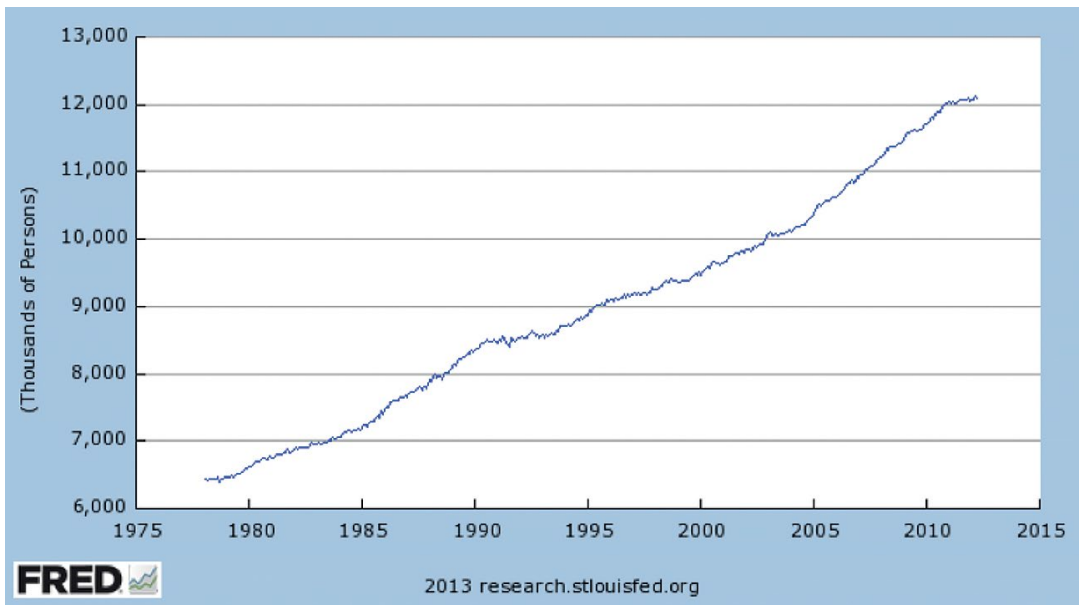

Figure 6.1: Civilian labour force: All persons in Australia.

Source: Organisation for Economic Co-operation and Development.

12 The civilian labour force includes all non-military people employed or seeking employment in Australia.

13 Trading Economics, 'Australia's Unemployment Rate', (7 November 2013). Available at: www.tradingeconomics.com/australia/unemployment-rate.

14 Australia Bureau of Statistics, Labour Force, Australia, Oct 2013 (7 November 2013). Available at: www.abs.gov.au/ausstats/abs@.nsf/mf/6202.0. 
Immigration advocates often argue that immigrants do the jobs Australians won't do. Critics of immigration often reply that if wages for these jobs were higher, Australians would be more willing to do them. However, this reply overlooks the fact that if wages were higher, many of the jobs simply wouldn't exist. For example, in the United States approximately one-third of all garment workers are immigrants. If wages needed to be higher to get Australians to take the jobs, many of these jobs would have gone overseas. Examples abound of farmers in the United States deciding that it was better not to produce than to pay higher wages. In Arizona, for example, only 30 per cent of the 2004 lettuce crop was harvested; the rest was left in the ground to rot. Losses amounted to nearly US $\$ 1$ billion. Farmers certainly could have paid higher wages to get the crop harvested, but the losses would presumably have been even greater.

\section{Immigrants don't depress wage rates}

This leads to the third most common economic objection to immigration. Any student who has taken an introductory economics course would think, quite plausibly, that if the supply of labour increases, more workers will be employed, but the wage rate will fall. The first part is true: as noted above, more workers are employed. However, the second part is not: wage rates do not necessarily fall. A survey of the economics literature on immigration concluded that '[d]espite the popular belief that immigrants have a large adverse impact on the wages and employment opportunities of the native born population, the literature on this question does not provide much support for the conclusion'. ${ }^{15}$

More research has been done since that survey was written, but the general conclusions remain much the same. ${ }^{16}$ Economists find no evidence of widespread declines in real wages. The debate on the

15 Rachel Friedberg and Jennifer Hunt, 'The Impact of Immigrants on Host Country Wages, Employment and Growth' (1995) 9 Journal of Economic Perspectives 23.

16 Sari Pekkala Kerr and William R Kerr, 'Economic Impacts of Immigration: A Survey' (NBER Working Paper 16736, 2011). 
effect of immigration on wage rates of native-born workers has mostly narrowed to the effect on wages of high-school drop-outs. ${ }^{17}$ Estimates range from slightly positive to, at worst, an 8 per cent fall. ${ }^{18}$

How is this possible? Don't the laws of supply and demand dictate that wages would fall? Not when other things change at the same time. Those immigrants who add to the supply of labour also demand goods and services, causing the demand for labour to rise. This means that the effect of immigration on wages shifts from being a theoretical question to being an empirical one. Figure 6.2 illustrates the three possible theoretical outcomes.

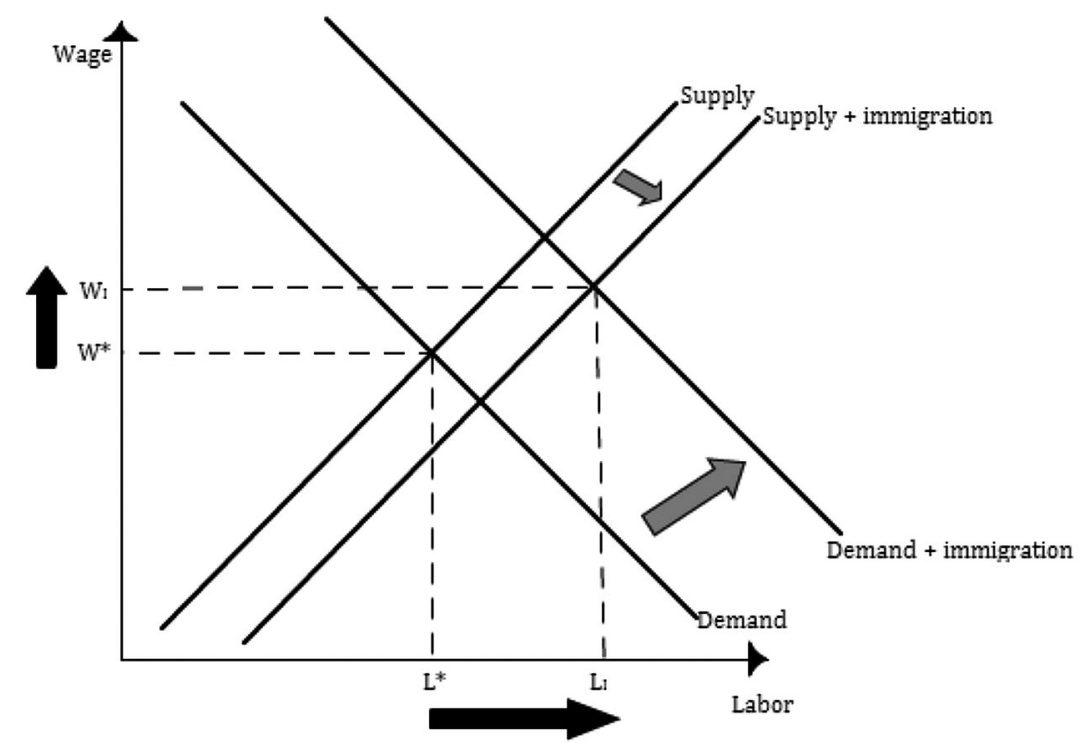

Figure 6.2a: Demand shift magnitude > supply shift magnitude.

Source: Author's research.

17 For a couple of classic examples in the conflicting sides of that debate, see George Borjas, 'The Labor Demand Curve is Downward Sloping: Reexamining the Impact of Immigration on the Labor Market' (2003) 118 Quarterly Journal of Economics 1335; David Card and Andrei Shleifer, 'Immigration and Inequality' (2009) 99 Australian Economic Review 1.

18 See Independent Institute's open letter, above fn 10, for references. 
UNINTENDED CONSEQUENCES

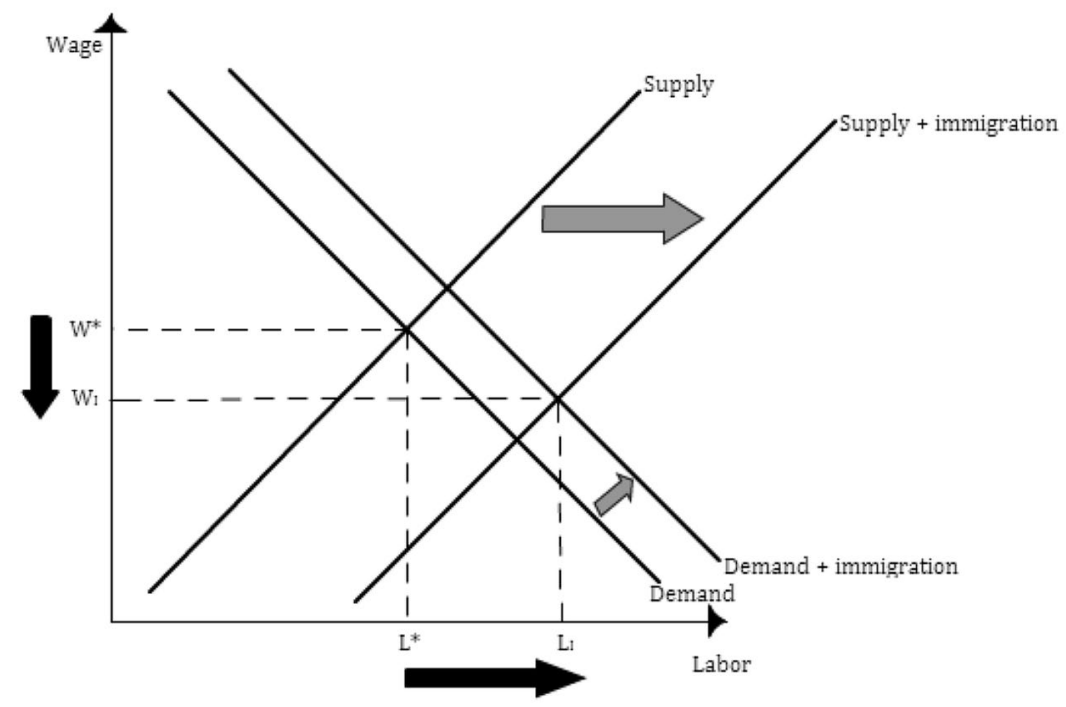

Figure 6.2b: Supply shift magnitude > demand shift magnitude.

Source: Author's research.

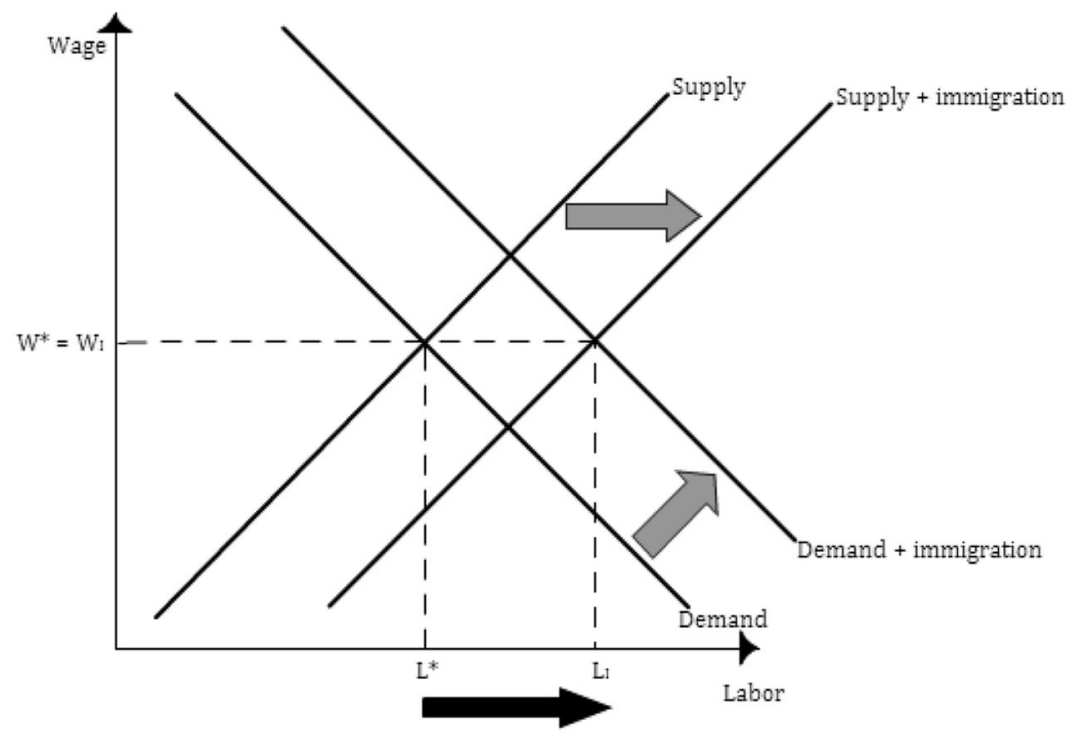

Figure 6.2c: Demand shift magnitude > supply shift magnitude.

Source: Author's research. 
In the first panel (Figure 6.2a) the demand for goods and services by immigrants is greater than the amount they increase the supply of labour, and wages rise. In the second panel (Figure 6.2b) their demand for goods and services is less than they increase the supply of labour, and wages fall. In the final panel (Figure 6.2c) immigrants' demand for goods and services are proportional to the increase in the supply of labour, and wages remain unchanged. Which of these three panels describes any particular country's experience is an empirical matter, not a theoretical one.

Second, immigrants don't simply shift the supply of labour. Labour is heterogeneous. When immigrants have skills that differ from those of the native born population, they complement the native born rather than serving as substitutes for them. Many immigrants are either extremely highly skilled or very low-skilled. ${ }^{19}$ Yet most native-born labour falls somewhere in between. To the extent that immigrants are complementing domestic labour, they can increase, rather than reduce, the wages of the native-born.

Third, even for the unskilled, the issue of price sensitivity needs to be taken into account. If the demand for workers is perfectly elastic in the relevant range, then there need not be any effect on wages. ${ }^{20}$ Finally, as Adam Smith pointed out centuries ago, specialisation and the division of labour are limited by the extent of the market. Bringing more immigrants into Australia expands the market and allows for greater specialisation. That makes each of us more productive and able to earn higher wages. This effect is particularly important in a country that is as large and yet sparsely populated as Australia.

\section{Fiscal impact of immigrants}

Another common fear is that immigrants are a fiscal drain on the government's budget. Some people might legitimately fear that changes to immigration policy would drain the federal budget or cause fiscal deficits. But because net economic gains flow from immigration, any

19 Evidence for the United States can be found in Matthew Hall et al., 'The Geography of Immigrant Skills: Educational Profiles of Metropolitan Areas' (Brookings Paper, 2011). Casual empiricism indicates that the same is likely true in Australia.

20 See Bryan Caplan's discussion of the contradiction within David Card's work on this point. Bryan Caplan, 'An Infinite Contradiction', EconLog, 19 May 2005. Available at: econlog.econlib. org/archives/2005/05/infinite_contra.html. 
budgetary imbalances should be solvable by changes to fiscal policy. Because immigration increases the size of the economic pie, re-cutting the pieces of the pie should be able to address fiscal concerns.

Nobel laureate economist Milton Friedman famously declared: 'You cannot simultaneously have free immigration and a welfare state. ${ }^{21}$ Many people take this to mean that immigration should be limited. However, the obvious alternative is to not allow immigrants access to the programs that comprise today's welfare state, including taxpayer-financed public education and healthcare programs. When Milton Friedman was asked about that alternative he commented: 'I haven't really ever thought of that system.'22 Luckily, a recent policy study by Alex Nowrasteh and Sophie Cole has considered this alternative system. ${ }^{23}$ Nowrasteh and Cole argue for building a wall around the US welfare state rather than a wall around the United States. They specifically suggest eliminating non-citizen access to Temporary Aid to Needy Families, Supplemental Nutrition Assistance Program, Supplemental Social Security Income, and Medicaid. Similar reforms would limit the desire of any future immigrants to come to Australia for access to the Australian welfare state. Of course there could be further unintended consequences of such a policy (see Chapter 4) but surely, at least from a potential immigrant's perspective, the offer of a migration visa without access to the welfare state is a much better deal than no visa at all.

\section{Other concerns about immigration}

Not all objections to greater migration are grounded in economic fallacies. It is beyond the scope of this paper to examine every objection to immigration, but there is one worth mentioning very briefly.

Australia has a high standard of living because it has a relatively good underlying economic institutional environment. An overwhelming scholarly literature has shown that greater economic freedom and a better security of private property rights cause higher standards

\footnotetext{
21 Peter Brimelow and Milton Friedman, 'Milton Friedman Soothsayer' (1998) 2 Hoover Digest. 22 Q\&A session with Milton Friedman at the 18th Annual Institute for Liberty and Policy Analysis (ISIL) World Libertarian Conference, 20-22 August 1999, San Jose, Costa Rica.

23 Sophie Cole and Alex Nowrasteh, 'Building a Wall Around the Welfare State, Instead of the Country' (Cato Policy Analysis 732, July 2013).
} 
of living and greater rates of economic growth. ${ }^{24}$ It is precisely this environment of economic freedom that makes immigration so economically beneficial. The 'Economic Freedom of the World Annual Report' is the best available measure of this environment. Australia currently ranks as the fifth freest economy in the world. ${ }^{25}$ Over the last 30 years Australia has never ranked below being the thirteenth freest economy.

One might fear that new immigrants will change the political environment and undermine political support for economic freedom, thus lowering the living standards of the native-born. Although possible, I think there are strong reasons to be sceptical of this fear. It is usually raised in the context of poorer, less skilled immigrants and refugees. But these immigrants overwhelmingly come from countries with much less economic freedom, and it is that environment that they are fleeing. It seems unlikely that refugees will want to transform Australia's institutions into those of the countries that they recently fled. More likely, as they assimilate into Australia's culture they will also assimilate Australian political ideology. My own recent research is the first to empirically investigate the topic. ${ }^{26}$ My co-authors and I examined how immigration impacted economic freedom in 110 countries from 1990 to the present. We find a small but positive increase in economic freedom caused by immigration while controlling for other factors.

\section{Conclusion}

The sorting mechanism that is best fitted for finding where immigrants should locate and what they should produce is the free market. In that setting, individuals and businesses contract voluntarily and wage rates balance against the cost of living, providing incentives to distribute the workforce efficiently, geographically and by sector. When labour mobility and wages are tightly controlled, shortages are the likely result.

24 See Joshua Hall and Robert A Lawson (eds), Economic Freedom: Causes and Consequences (Nova Science Publishers, 2011); Benjamin Powell, Making Poor Nations Rich: Entrepreneurship and the Process of Development (Stanford University Press, 2008).

25 James Gwartney, Robert Lawson and Joshua Hall, ‘Economic Freedom of the World: 2013 Annual Report' (Fraser Institute).

26 J R Clark et al., 'Does Immigration Impact Economic Freedom?' (CATO Working Paper, 2014). 
It is important to consider the question of whether policy-makers could possibly know the right or optimal quota level. Knowledge of labour market conditions is dispersed throughout the economy, and government planners do not know the specific circumstances of time and place as well as entrepreneurs and workers on the spot. ${ }^{27}$ Central planning of economic activity has a dismal track record, and the labour market is not fundamentally different from other markets that are impossible to plan. Market conditions are changing constantly, and any quota that might seem appropriate for one time and place will not work in another. The prices and quantities of labour, like other goods and services, need to be continually discovered anew by decentralised bidding between workers and employers. Absent this process, no one knows the right quantity of labour in any given sector.

Eliminating immigration barriers to skilled workers from other wealthy countries should be the least controversial policy change. Much like Australians choosing to migrate between states, there appears to be little concern amongst the public and policy-makers that high-skill immigrants will come for welfare benefits, be criminals, or undermine political institutions. As a policy tool, this cohort presents an easy demographic for governments to encourage. They have high skills and most people understand the ways that they can benefit the Australian economy.

But immigration restrictions on low-skilled workers from poorer countries should also be eliminated. These workers are not an economic burden upon the native-born. The greatest welfare gains for the world economy come from admitting these workers. These workers free up time for more highly skilled Australians to perform other valuable services and do not systematically depress the wages of the native-born. Even if they are a fiscal drain, the appropriate response is to allow them entry and to rearrange fiscal policy so that they cease to be a drain. Because they increase the size of the economic pie, any fiscal drain is a result of poor policy, not an inherent necessity of low-skilled immigration. There is little evidence to suggest that these immigrants do anything to undermine the economic institutions that make Australia wealthy. An open immigration policy for all high-skill and low-skill workers, from rich and poor countries would make would-be immigrants much better off and make nativeborn Australians wealthier too.

27 F A Hayek, 'The Use of Knowledge in Society' (1945) 35 American Economic Review 519. 


\section{Bibliography}

Australia Bureau of Statistics, Labour Force, Australia, Oct 2013 (7 November 2013). Available at: www.abs.gov.au/ausstats/abs@. $\mathrm{nsf} / \mathrm{mf} / 6202.0$

Bastiat, Frédéric, 'What Is Seen and What Is Not Seen' in George B. de Huszar (ed.) Seymour Cain (trans.), Selected Essays on Political Economy (Foundation for Economic Education, 1848)

Borjas, George, 'The Labor Demand Curve is Downward Sloping: Reexamining the Impact of Immigration on the Labor Market' (2003) 118 Quarterly Journal of Economics 1335

Borjas, George, 'Immigration' in David R Henderson (ed.), The Concise Encyclopedia of Economics (Liberty Fund, 2009) 253

Brimelow, Peter and Milton Friedman, 'Milton Friedman Soothsayer' (1998) 2 Hoover Digest

Caplan, Bryan, 'An Infinite Contradiction', EconLog, 19 May 2005. Available at: econlog.econlib.org/archives/2005/05/infinite_contra. html

Card, David and Andrei Shleifer, 'Immigration and Inequality' (2009) 99 Australian Economic Review 1

Clark, J R, Robert A Lawson, Alex Nowrasteh, Benjamin Powell and Ryan Murphy, 'Does Immigration Impact Economic Freedom?' (CATO Working Paper, 2014)

Clemens, Michael, 'Economics and Emigration: Trillion-Dollar Bills on the Sidewalk?' (2011) 25 Journal of Economic Perspectives 83

Cole, Sophie and Alex Nowrasteh, 'Building a Wall Around the Welfare State, Instead of the Country' (Cato Policy Analysis 732, July 2013)

Friedberg, Rachel and Jennifer Hunt, 'The Impact of Immigrants on Host Country Wages, Employment and Growth' (1995) 9 Journal of Economic Perspectives 23

Gwartney, James, Robert Lawson and Joshua Hall, 'Economic Freedom of the World: 2013 Annual Report' (Fraser Institute) 
Hall, Joshua and Robert A Lawson (eds), Economic Freedom: Causes and Consequences (Nova Science Publishers, 2011)

Hall, Matthew, Audrey Singer, Gordon F De Jong and Deborah Roempke Graefe, 'The Geography of Immigrant Skills: Educational Profiles of Metropolitan Areas' (Brookings Paper, 2011)

Hayek, F A, 'The Use of Knowledge in Society' (1945) 35 American Economic Review 519

Organisation for Economic Co-operation and Development, Civilian Labor Force: All Persons in Australia (C) [AUSLFTOTADSMEI] (2012). Available from: ALFRED, Federal Reserve Bank of St Louis alfred.stlouisfed.org/series?seid=AUSLFTOTADSMEI

Organisation for Economic Co-operation and Development, 'Key Indicators on International Migration'. Available at: www.oecd. org/els/mig/keyindicatorsoninternationalmigration.htm

Pekkala Kerr, Sari and William R Kerr, 'Economic Impacts of Immigration: A Survey' (NBER Working Paper 16736, 2011)

Powell, Benjamin, Making Poor Nations Rich: Entrepreneurship and the Process of Development (Stanford University Press, 2008)

Powell, Benjamin and Zachary Gochenour, 'Broken Borders: Government, Foreign-born Workers, and the US Economy' (Policy Report, The Independent Institute, September 2013)

Ricardo, David, On the Principles of Political Economy and Taxation (Cambridge University Press, 1817)

Simon, Julian, The Ultimate Resource (Princeton University Press, 1981)

Smith, Adam, An Inquiry into the Nature and Causes of the Wealth of Nations (W Strahan and T Cadell, 1776)

Tabarrok, Alexander and David Theroux, 'Open Letter on Immigration', Independent Institute, 19 June 2006. Available at: www.independent.org/newsroom/article.asp?id=1727

Trading Economics, 'Australia's Unemployment Rate', 7 November 2013). Available at: www.tradingeconomics.com/australia/ unemployment-rate 
This text is taken from Unintended Consequences: The impact of migration law and policy, edited by Marianne Dickie, Dorota Gozdecka and Sudrishti Reich, published 2016 by ANU Press, The Australian National University, Canberra, Australia.

The papers published in this book arose from an inaugural conference on migration law and policy at ANU College of Law, held in October 2013. They are reprinted here with minor amendments. 